\title{
Revisiting "In a Different Voice"
}

\author{
Carol Gilligan
}

\begin{abstract}
In 1982 Harvard University Press published Carol Gilligan's landmark work, In a Different Voice, a book on psychological theory and women's development, which sparked a heated discussion in the world of psychology. After listening to women speaking about themselves and about morality, Gilligan noticed that psychologists would study men and generalize to humans, and decided to explore the different voice she had heard. That became the basis of her book. In this interview she explains the origins of the book, how the book was received by the psychological community at the time, and why it had the impact that it did.
\end{abstract}

Can you share with us what early life experiences contributed to your becoming an academic?

Your question absolutely stops me because I never set out to become an academic. Why did I end up writing? Why did I end up writing about voice? Why did I end up teaching and why did I end up in the university world? It was not that I set out to do it. And I do tell the story at the beginning of my book, "Joining the Resistance," about when I was two years old and my parents took me to this educational program at Vassar College for children and their parents. And the children were in one building, and the parents were in another-they thought they were running a kibbutz or something! Anyway, I loved the school and I loved my teacher, but I wanted my mother. And I was the child who just insisted, who cried and cried that I had to have my mother come and put me to bed. And they just changed the rules, and my mother came and sang me to sleep. So you could say I learned at a very early age about the effectiveness of voice. As a child I loved stories. I have always loved literature-that's what I studied in college. I also was very involved in music and singing. When I came into the field of psychology, it makes sense that I would be someone who would listen and ask, "Who's speaking"? The sort of questions you ask if you are used to thinking about stories. "Who's speaking to whom?" and in what societal and cultural frameworks? That's the origin of my work.

When I left college, I really wasn't sure what I was going to do. I went to graduate school thinking I wanted to become a therapist. But my love was for literature. Then I was very involved with the civil rights movement and I did voter registration. If you think about this, if you want to make the theme, I was saying to people: "You need to have a voice." Sometimes I say to myself that, "I'm a novelist who happened to wander into the world of psychology and listened to the conversation." In a Different Voice originated with my saying, "Wait a minute, what the field of psychology presents as the truth is a voice. And how do you show that? By introducing a different voice." At that point I got very invested in research and that's how I started, then one thing led to another. 
In a retrospective on your renowned and pivotal 1982 work, "In a Different Voice," what alerted you to the fact that the voices of women were missing from the study of moral development and what had readied you to listen to these stories?

I have to just thank you for this question because it's such a clear reading of my book: "What alerted me to the fact that the voices of women were missing?" Because if you think about that, for a psychologist, that's a huge error because in history women may not have been that essential, but to a psychologist, women are half the sample of humans. How had intelligent psychologists—I worked with Erik Erikson; I worked with Lawrence Kohlberg-somehow left out half the sample? But that's not the way I was thinking. I was interested in stories. I was very interested in the points in life when people come to a crossroads. We all do this, where we come to a place and the roads diverge, and you think, "Which way am I going to go?" And who's the "I" in the sentence, "What am I going to do?" and does moral language come into play? What's the right thing to do? What should I do?

I had worked with Erik Erikson, who worked on identity ... this was really the opportunity I had being at Harvard was to work with the people who had created the theories ... it's like I had a close-up. I thought asking people hypothetical questions: it's easy to say what some hypothetical person should do. What about if you're actually on the line? But that's what I was interested in: what happens when you're actually there and you're going to live with your choice. Who's the "I" that makes the choice and where does morality and culture come in?

What happened is I was teaching discussion sections in Kohlberg's class on moral and political choice. This was in 1972-it was the height of the anti-war protests. I had these very articulate Harvard students in my class and they all thought the Vietnam War was unjust-this was a course on moral and political choice. And then there was a week when we were talking about the Draft, the Vietnam War Draft. And I noticed, suddenly, all of these men-these very articulate men-became silent. And I thought: "This is interesting. How come they've suddenly stopped talking?" Well, that was not hypothetical. When they were seniors in college, they were going to face the Draft. So, I became very curious about what men were not saying. And why they were not talking about the Draft ... when it came to it, were they going to resist the draft ... were they going to go to Canada ... were they going to go to jail? They were concerned, not only about was the War in some abstract sense a just war or unjust war. They were concerned with how would their response to the Draft affect people they cared about and also with their own feelings about going to jail or leaving the country-they were concerned about emotions and relationships as well as about upholding their sense of themselves and their moral principles. And they knew because they were studying with Kohlberg, that to be concerned about relationships and emotions was to sound like women and be at a lower stage of moral development, according to Kohlberg's scale. So, they weren't going to be hypocritical; basically their integrity had led them to say nothing. I thought: "Fine. I'Il wait until they're seniors and then I'Il interview these guys and see what are they going to do and how will they speak about their decision." That is (as it was called in the field?), I would study the relationship between judgment and action. Well, in 1973 President Nixon ends the Draft—-that's when they became seniors, so there went my study. 
But then the Supreme Court legalizes abortion. I think: "Oh, here's another group of people who have to make a decision in a finite period of time, and it's an either/or-you can't both have an abortion and have a baby." It fit what I was interested in. So, with Mary Belenky, who was a graduate student at the time working with me, we start interviewing people who are facing an actual conflict and choice and our first question was in essence: "What is the choice you are facing and how have you been thinking about it so far?" Our first question to these women was-and this was in street-front clinics in the South end of Boston, and at pre-term and planned parenthood and university counselling (we're all over the city)—anyone who was in the first trimester of a confirmed pregnancy who was thinking about abortion ... we would come and we said, not, "Do you believe in the right to life or the right to choice?" Instead we asked: "How did you get pregnant and how have you been thinking about it so far?" And the teenagers looked at us as if to say: "Really, you adults don't know anything!" But then we went on to ask: "What alternatives are you considering and how are you thinking about each? Who's involved in making this decision?" And then, finally: "Is there a right way to make this decision, right just for you or for anyone?"

I remember, my friend Dora came over one afternoon. I was reading the transcripts of these interviews and I said to her: "You know, Dora, I understand why Freud and Piaget, Erikson and Kohlberg are having so much trouble understanding women, because many of these women are constructing the problem differently. They're starting from a different set of premises." And she said: "That's interesting. Why don't you write about it?" And so I wrote: "In a different voice: Women's conceptions of the self and of morality" - the paper published in 1977 that then led to the book. Listening to women speaking about themselves and about morality, I could see also why so many women felt-and I could also relate to this - that if we said what we really thought and felt, we would not be listened to; we would be corrected, told how we should think and feel or what was the right way to think and feel about ourselves and about morality. I understood why so often women felt unheard and misunderstood. In a Different Voice is about a different way of framing self and morality, and relationships and choice. For many women, the dilemma posed by the question of whether to continue or abort a pregnancy was a dilemma of relationship.

In a Different Voice was the first thing I wrote that was not for school. It was a paper that I wrote for myself. And that's when I noticed the extent to which psychologists in building their theories of human psychology had been studying men (and I would add, mostly privileged, white men) and generalizing to humans. In essence, my work asked the question ... : "Can you really leave out women and miss nothing of significance?" Because the only question that was being asked about women is: "Are women the same as men or different from men?" And if women are not the same as men, then: "Who's better? (more moral, more developed)" And to me, those were not very interesting questions. I was interested in what had been missed by leaving out women. And then I saw how bringing in women's voices disrupted psychological theory because it gave voice to a world of relationships within a framework that valorized separation. 
The book comes out and that's when I get committed to being in the university-your initial questionI'm teaching part-time, I have three children, I'm a modern dancer, I'm a civil rights worker, anti-war ... another mother for peace. I'm not looking for tenure at Harvard. I'm operating in a very free space and suddenly everybody is saying, "This book, who are you?" First of all, it was an amazing moment in psychology because I remember I was going around giving talks because everyone was inviting me, and it was like a public confession. Men would get up and say, "I published my study on achievement or on this or on that, and I realized I never reported my data on women because it didn't make any sense ... I don't think I said that in the article." I felt people kept wanting to argue with me: "Are women the same as men?" I did not do a statistical study. My book is called In a Different Voice-honestly you need an $n$ of 1 to write a book about a different voice. Here's a voice, here's a different voice ... it's interesting to say here's a voice and here's a variation of this voice, or here's how this voice changes or develops over time, and so forth. I wasn't writing about women versus men, but my work kept being assimilated to this framework where the two questions were: "Are women the same as men or are they different from them? And if different, who's better?" To me, as a literary person the answer is both: we're the same and we're different. And then, "If women are different, who's better?" "Are women more moral than men, are women less developed than men?" I'Il tell you honestly, I wanted out of that conversation. I really wanted out of that conversation. And I really wanted out of the effort that was going into it by people who had a vested interest in the status quo, including people like Erikson who asked in effect, "Do you want me to change my chart?" Just because for women the sequence of stages is a bit different (which is what Erikson had written), why should he change his chart of the human life cycle? Or Kohlberg: "Do you want me to change my stage theory"? In fact, Larry [Kohlberg] and I taught together for several years around the question: did my work imply a "b" route through his stages (which is what he thought) or did it imply a reformulation of moral development? We argued this in front of students as you do in the academic world. But after a while, I felt I kept being drawn back to step one of my work (did it really make a difference to have left out women, was nothing missed by not listening to women) and I feared I was going to become a prisoner of my early work.

In In a Different Voice, the single voice that many women readers found most unsettling was the voice of the one 11-year-old girl in the book. Some people say that In a Different Voice is a book about children's moral development. Well, there are literally two children in the book and they appear for about five pages, and I'm delighted that people remember Jake and Amy and they made such a big impression. But, what's more interesting to me about In a Different Voice is what is not talked about: the abortion study, which is the focus of its two central chapters. By casting the book as a book about children's moral development, people overlook that it's a book filled with women's voices that explores a dissonance between women's voices and the voices of psychological theory. That's the contrast. Here's are the voices of psychological theory intoning separation, autonomy, and independence, and here are women's voices speaking about relationships and interdependence.

When 11-year-old Amy says — she was asked if a man, Heinz, should steal an overpriced drug to save the life of his wife who's dying- "He shouldn't steal, the wife shouldn't die, there must be another way 
to solve this problem," her response sounds wishy-washy, she's indecisive. She explains that stealing is not a good way to solve this problem because if he stole the drug now and she got sick again, then he would be in jail and she'd be alone, and then what ... and you think, "Well, that makes a lot of sense." But if you're a woman in the university you also think but that's not the right way to think about this problem. So, my writing about Amy picked up on that inner discussion many women will have with themselves. Amy says about Heinz and the druggist: "The two of them should just talk it out and find some better way to solve the problem." So, that was the voice that got to many women.

I had walked into an intersection of psychology and culture, where there's a psychological resistance to entering a cultural framework that's going to undermine basic human capacities, by splitting reason from emotion, the mind from the body and the self from relationship—splits that psychological theory and in particular theories of psychological development had bought into at that time. And girls, narrating their coming of age were narrating the resistance and also narrating the incoherence of these splits. They felt, "If I can't say what I'm feeling and thinking if I want to have relationships, then actually I can't have relationships because if I'm not saying what I'm feeling and thinking, I won't be present."

I discovered that if you follow girls' development from childhood into adolescence and have girls narrate their experiences in coming of age, what you encounter is the tension between human psychology and the culture of patriarchy. And that discovery completely changed my work.

\section{What suggestions do you have for educators in schools to foster situational and relational moral} reasoning?

Relational thinking is where we all start from, at the beginning, we're born with a voice-with the ability to communicate our experience and with the desire to engage responsively with others, that is to live in relationship. My studies with girls revealed that what psychologists had called "development" — the separation of reason from emotion, the separation of the self from relationships ... that's the move from a relational thinking to separate thinking. The separation of reason from emotion, mind from the body, the self from relationship: it's not development-it's an initiation. And now with the work of Damasio [who] says his separation of reason from emotion is not the achievement of rationality, it's a manifestation of injury or trauma. There's an initiation with girls that tends to take place at adolescence, but with boys it happens earlier, between four and seven. That was the work I did after the girls' work. My former student Judy Chu has written a brilliant book called, "When Boys Become Boys." She demonstrates that much of what's said about boys is not how boys are, but it's how boys may feel they have to become in order to be recognized as real boys. These are the times when kids in school start to show signs of psychological distress. For the little boys, the boys roughly between four and seven-the reading problems, the learning problems, the speech problems, the out-of-touch and out-of-control behavior, the signs of listlessness and depression that you see more in young boys than in young girls-school is where this is going on. And it's true also for girls at the time of their initiation which tends to be at adolescence, when they are becoming young women. That's when there is a sudden high incidence of depression, eating disorders, cutting, and other forms of destructive behaviour. And the school's role: Is the school invested in this initiation? Is the school the agent of this initiation? Or is the school aligned with a healthy 
resistance in the child and will the school join and educate their resistance? That's my question. It's absolutely key. I have a student right now who just did a beautiful interview showing that the alternative to resistance in the children is disconnection. That is, they disconnect from the school. So, to me, schools are key.

\section{References}

Chu, J. (2014). When boys become boys. New York, NY: New York University Press.

Gilligan, C. (1977). In a different voice: Women's conceptions of self and morality. Harvard Educational Review, 47, 481-517.

Gilligan, C. (1982). In a different voice: Psychological theory and women's development. Cambridge, MA: Harvard University Press.

Gilligan, C. (2011). Joining the resistance. Cambridge, UK: Polity Press.

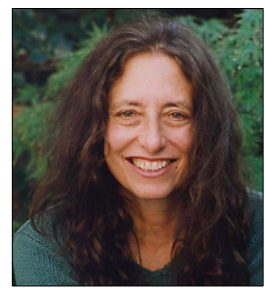

Carol Gilligan is currently a University Professor at New York University; she was the Patricia Albjerg Graham Professor of Gender Studies at Harvard and the visiting Pitt Professor of American History and Institutions at the University of Cambridge. Following In a Different Voice, she published five books with her graduate students, including Meeting at the Crossroads: Women's Psychology and Girls' Development with Lyn Mikel Brown, a 1992 New York Times notable book of the year. Her books include The Birth of Pleasure: A New Map of Love, and Kyra: A Novel. She received a Heinz award for her contributions to understanding the human condition and a Grawemeyer award for her contributions to education. In 1996, she was named by TIME magazine as one of the 25 most influential Americans. 